\begin{tabular}{|c|c|c|}
\hline & International Journal of Current Research in \\
Biosciences and Plant Biology \\
EXCELLETT \\
PUBLISHERS
\end{tabular}

\title{
Effect of Application of Vermicompost, Cowdung, Neem Cake and Biofertilizer on Growth and Yield Responses of Cotton (Gossypium hirsutum L.)
}

\section{R. Annadurai ${ }^{1}$ and R. Nelson ${ }^{2 *}$}

1Department of Botany, Arignar Anna Government Arts College, Musiri - 621 211, Tamil Nadu, India 2Department of Botany, Government Arts College, Ariyalur - 621704, Tamil Nadu, India

${ }^{*}$ Corresponding author.

\begin{tabular}{|c|c|}
\hline Article Info & ABSTRACT \\
\hline $\begin{array}{l}\text { Date of Acceptance: } \\
15 \text { June } 2018\end{array}$ & \multirow{4}{*}{$\begin{array}{l}\text { Pot experiments were carried out to study the comparative efficiency of individual and } \\
\text { combined application of organic manures (vermicompost, cowdung, neem cake) and } \\
\text { biofertilizer on growth, biochemical properties and yield of cotton, Gossypium hirsutum } \\
\text { L. in botanical garden, Department of Botany, Government Arts College, Musiri. } \\
\text { Treatments were organic manures, single, combined application biofertilizer and } \\
\text { control (without manures). The obtained results revealed that the response of cotton } \\
\text { plant (Gossypium hirsutum L.) showed more significantly increased germination, } \\
\text { growth and biochemical characteristics in combined inoculation of different organic } \\
\text { manures (biofertilizer + vermicompost + cowdung + neem cake). The minimum } \\
\text { germination, growth and biochemical characteristics were observed in the control. On } \\
\text { the whole, combined application of organic manures increased the qualitative and } \\
\text { quantitative properties of cotton plant significantly when compared to control. }\end{array}$} \\
\hline $\begin{array}{l}\text { Date of Publication: } \\
\text { 06 July } 2018\end{array}$ & \\
\hline Keywords & \\
\hline $\begin{array}{l}\text { Biofertilizers } \\
\text { Biochemical properties } \\
\text { Gossypium hirsutum } \\
\text { Organic manure } \\
\text { Vermicompost }\end{array}$ & \\
\hline
\end{tabular}

\section{Introduction}

Cotton is an important commercial crop of India, grown by four million farmers in an area of 7.4 million hectares. India occupies the foremost position in acreage, which is almost $25 \%$ of the global cotton area. Cotton enjoys a predominant position amongst all cash crops in India. Cotton is an important raw material for the Indian textile industry, constituting about 65 per cent of its requirements. The Indian textile industry occupies a significant place in the country's economy with over 1500 mills, 4 million handlooms, 1.7 million power looms and thousands of garment, hosiery and processing units, providing employment directly or indirectly to around 35 million people (Sankaranarayanan et al., 2011).

However, the productivity of cotton is very low in India and its production contribution is only $9 \%$ compared with $22 \%$ in China and $19.4 \%$ U.S (FAO, 2009). The lint productivity of cotton is $322 \mathrm{~kg} \mathrm{ha}^{-1}$, 
which is the lowest and far below that of the world average of $627 \mathrm{~kg} \mathrm{ha}^{-1}$ (Shivagaje et al., 2004).

Cotton is a very important cash crop for smallholder farmers, but also one of the most exigent crops in terms of agrochemical inputs which are responsible for adverse effects on human health and the environment (Bachmann, 2012). Kimenju et al. (2004) reported that application of organic amendments stimulated the activity of natural antagonists of plant parasitic nematodes. The fibre is most often spun into thread and used to make a soft, breathable textile, which is the most widely used natural-fibre cloth in clothing today (Dumka et al., 2004). Use of organic manures is helpful to healthy environment. Therefore use of organic manures in stable agriculture not only increase the population of useful microorganisms, but also add the nutritious elements such as nitrogen, phosphorus, magnesium and potassium in the soil which improve the growth and activity of the crops (Kumar and Singh, 2001). The present study was undertaken to evaluate the performance of organic amendments under pot condition for cotton plant.

\section{Materials and methods}

The experiment was carried out in pot culture experiment at the Department of Botany, Arignar Anna Government Arts College, Musiri, Tamil Nadu. Seeds of cotton (Gossypium hirsutum L.) were obtained from National Agriculture Research Centre (NARC), Coimbatore. Following treatments were made.

Control (no amendments)

$$
\begin{aligned}
\mathrm{T} 1= & \text { Azospirillum } \\
\mathrm{T} 2= & \text { Vermicompost } \\
\mathrm{T} 3= & \text { Cowdung } \\
\mathrm{T} 4= & \text { Neem cake } \\
\mathrm{T} 5= & \text { Azospirillum + vermicompost }+ \text { cowdung }+ \\
& \text { Neem cake }
\end{aligned}
$$

Effects of organic amendments were evaluated by determining the plant shoot length and root length measured by using centimeter scale and their fresh weight was taken by using an electrical single pan balance. The fresh plant materials were kept in a hot air oven at $80^{\circ} \mathrm{C}$ for $24 \mathrm{hrs}$ and then their dry weight were also determined. Biochemical properties, such as protein, amino acid, total sugar and starch contents of the plant were analysed using standard biochemical methods. The protein content was determined according to the method of Lowry et al. (1951). The amino acid content was analyzed by Moore and Stein (1948). Total sugar content was analyzed by the method of Nelson (1944) and starch content was analyzed by Dubois (1956) method.

\section{Results and discussion}

Figs. 1 and 2 clearly reveal the influence of different soil amendments (neem cake, cowdung, vermicompost, biofertilizer) on shoot length and root length of cotton (Gossypium hirsutum L.) in 25, 50 and 75 days after sowing (DAS) with respect to control. The lowest shoot length and root length was observed in control soil, while the shoot length and root length was significantly increased in all the soil amendments in both days. The highest shoot length and root length were observed in combined application of soil amendments (neem cake + cowdung + vermicompost + biofertilizer). This resulted due to the improved growth status of plants because of the presence of organic amendments in the soil.

Figs. 3 and 4 show the effect of different soil amendments (neem cake, cowdung, vermicompost, biofertilizer) on fresh weight and dry weight of cotton (Gossypium hirsutum L.) in 25, 50, 75 DAS with respect to control. The lowest fresh weight and dry weight was observed in control soil. The fresh weight and dry weight was significantly increased in all the soil amendments in both days. The highest fresh weight and dry weight were observed in combined application of soil amendments (neem cake + cowdung + vermicompost + biofertilizer). It may be due to the improved growth status of plants because of the presence of organic amendments in the soil. Oliveira et al. (2009) who reported that the using organic manures increased the performance of all lettuce characteristics like fresh and dry leaf mass, fresh and dry stem mass, stem length, fresh root mass, fresh head mass, and commercial yield. 


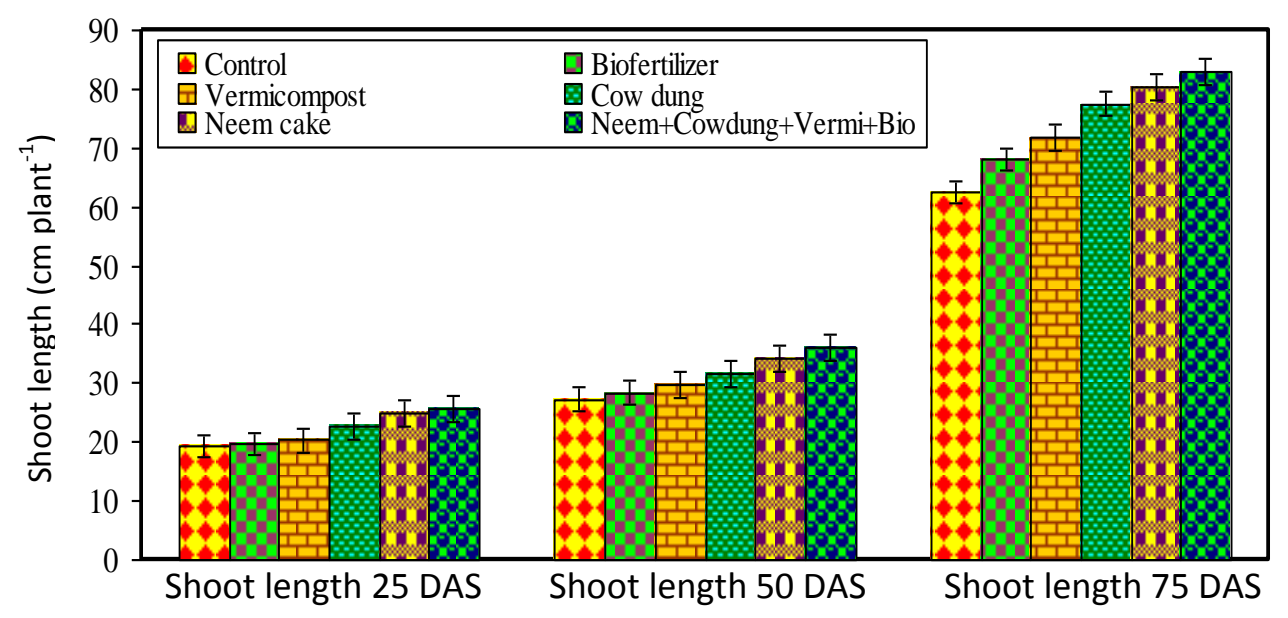

Fig. 1: Effect of different soil amendments on shoot length of cotton (Gossypium hirsutum L.). DAS days after sowing. Error bars indicate \pm SD.

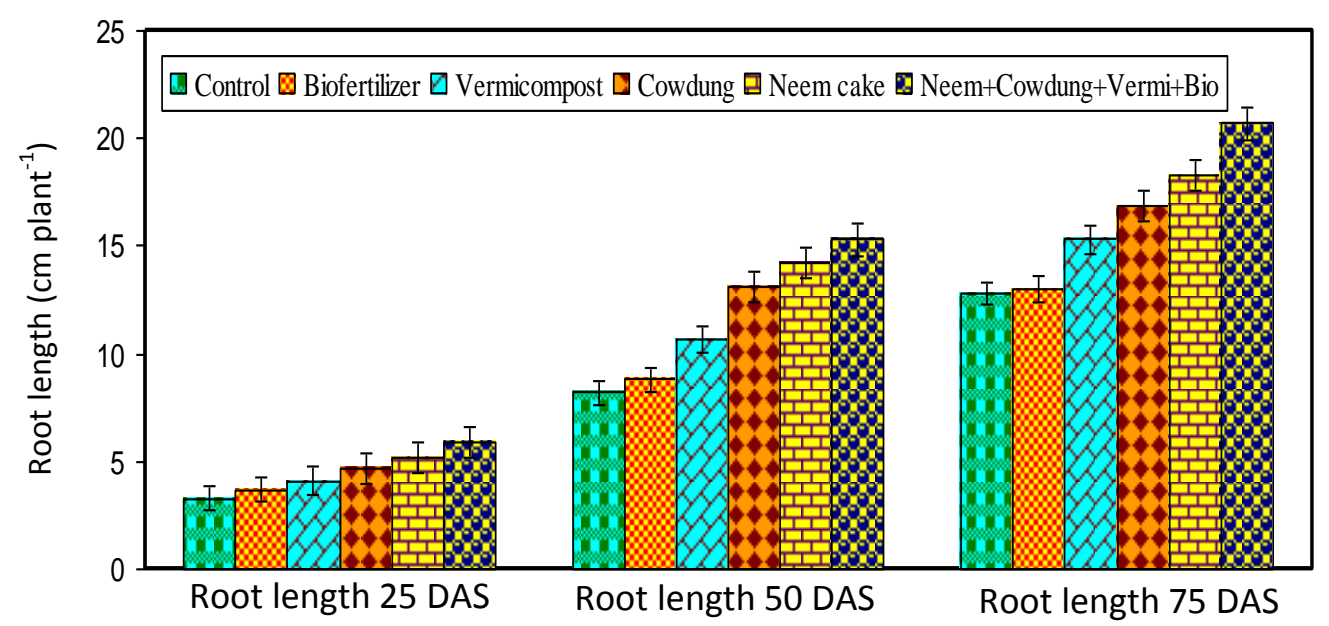

Fig. 2: Effect of different soil amendments on root length of cotton (Gossypium hirsutum L.). DAS days after sowing. Error bars indicate \pm SD.

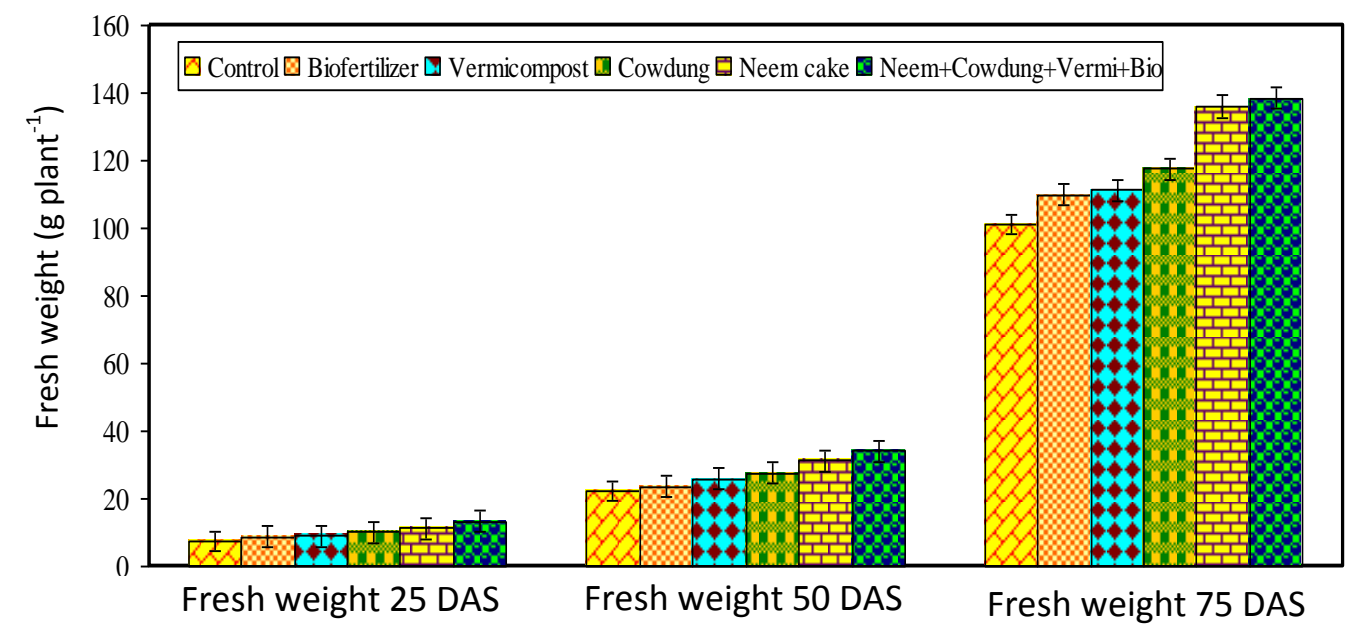

Fig. 3: Effect of different soil amendments on fresh weight of cotton (Gossypium hirsutum L.). DAS days after sowing. Error bars indicate \pm SD. 


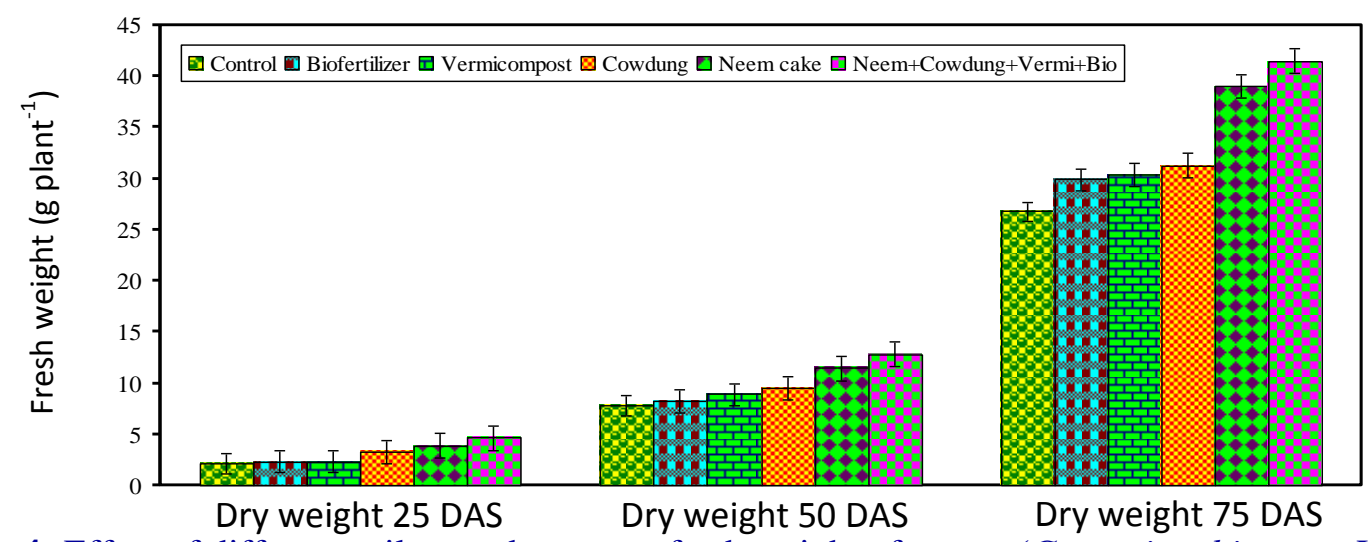

Fig. 4: Effect of different soil amendments on fresh weight of cotton (Gossypium hirsutum L.). DAS days after sowing. Error bars indicate \pm SD.

Figs. 5, 6, 7 and 8 represent the effect of different soil amendments such as neem cake, cowdung, vermicompost, biofertilizer and neem cake + cowdung + vermicompost + biofertilizer on protein, amino acid, total sugar and starch contents of cotton plant in 25, 50 and 75 DAS with respect to control.
The lowest protein amino acid, total sugar and starch were observed in control. The protein amino acid, total sugar and starch were significantly increased in all the soil amendments. The highest protein amino acid, total sugar and starch have been obtained from combined application of soil amendments.

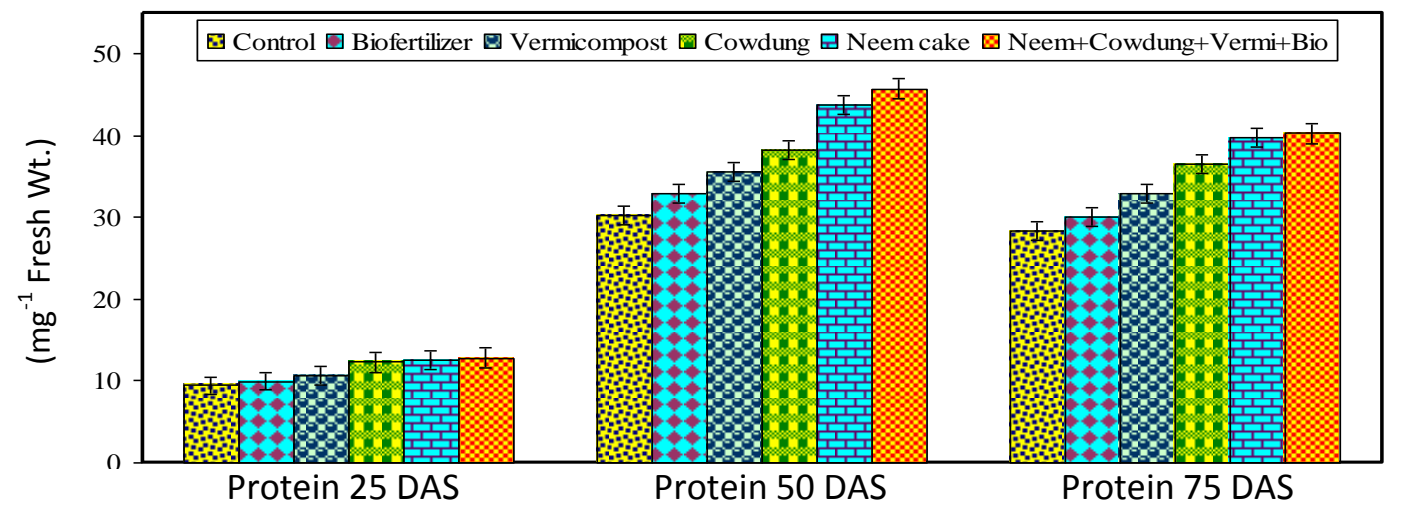

Fig. 5: Effect of different soil amendments on protein content of cotton (Gossypium hirsutum L.). DAS - days after sowing. Error bars indicate \pm SD.

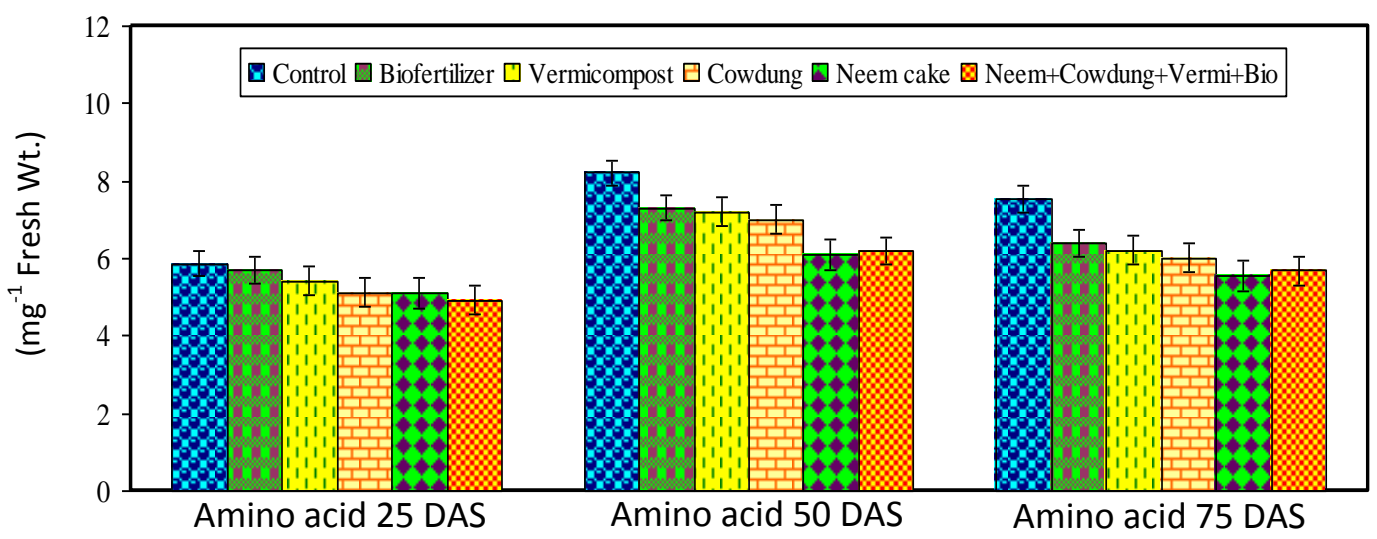

Fig. 6: Effect of different soil amendments on amino acids content of cotton (Gossypium hirsutum L.). DAS - days after sowing. Error bars indicate \pm SD. 


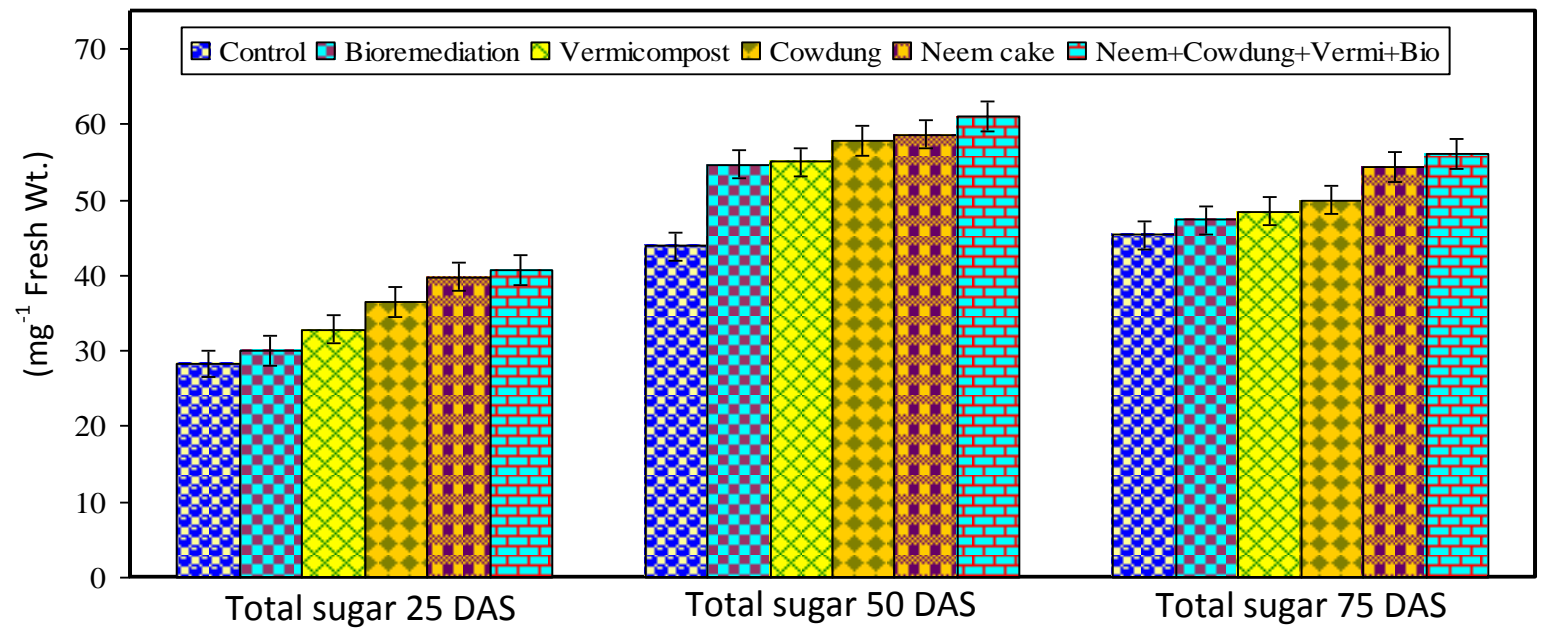

Fig. 7: Effect of different soil amendments on total sugar content of cotton (Gossypium hirsutum L.). DAS - days after sowing. Error bars indicate \pm SD.

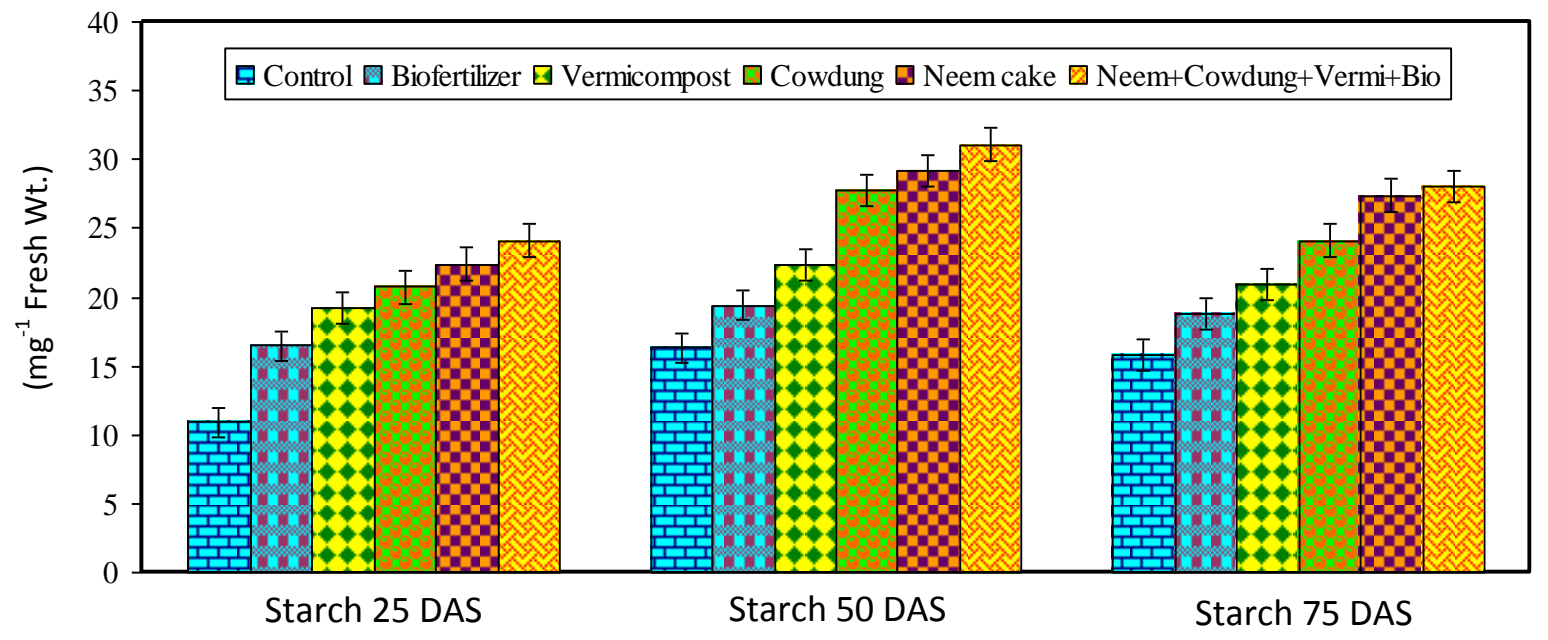

Fig. 8: Effect of different soil amendments on starch content of cotton (Gossypium hirsutum L.). DAS - days after sowing. Error bars indicate \pm SD.

Figs. 9 and 10 demonstrate the effects of various soil amendments (neem cake, cowdung, vermicompost, biofertilizer and neem cake + cowdung + vermicompost + biofertilizer) number of bolls per plant and weight of bolls of the cotton plant, Gossypium hirsutum L.) in 25, 50 and 75 DAS with respect to control. The lowest number of bolls per plant and weight of bolls were observed in control soil, whereas the number of bolls and weight of bolls were significantly higher in all the soil amendments. The maximum number of bolls and weight of bolls was found in pots which received combined application of soil amendments (neem cake + cowdung + vermicompost + biofertilizer). The analysis of plant yield parameters showed significant variations in the number of bolls and weight of bolls among the different soil amendments. Similar observations were reported by Falaki et al. (1992) who reported significant increases in maize yield components with the addition of organic manure. The amendment of vermicompost alone as organic manure and vermicompost in combination with chemical fertilizers showed improved growth and yield characteristics of Lablab purpureus (Karmegam and Daniel, 2008). 


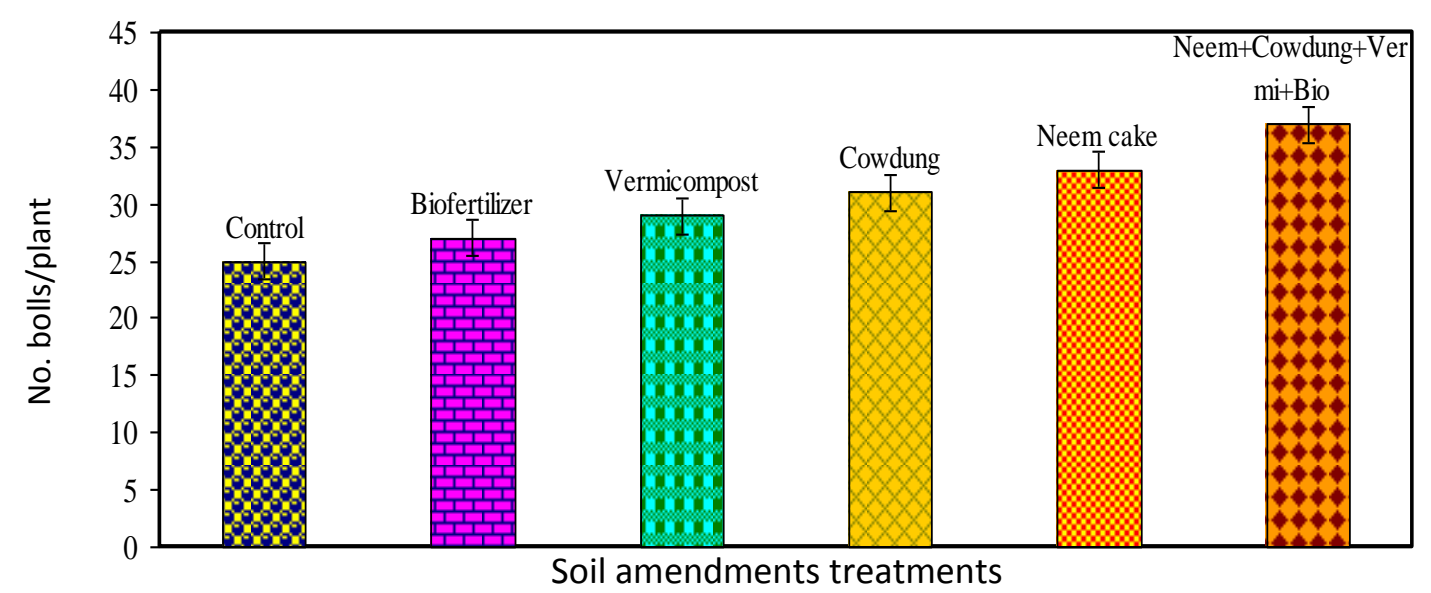

Fig. 9: Effect of different soil amendments on number of bolls/plant of cotton (Gossypium hirsutum L.). DAS - days after sowing. Error bars indicate \pm SD.

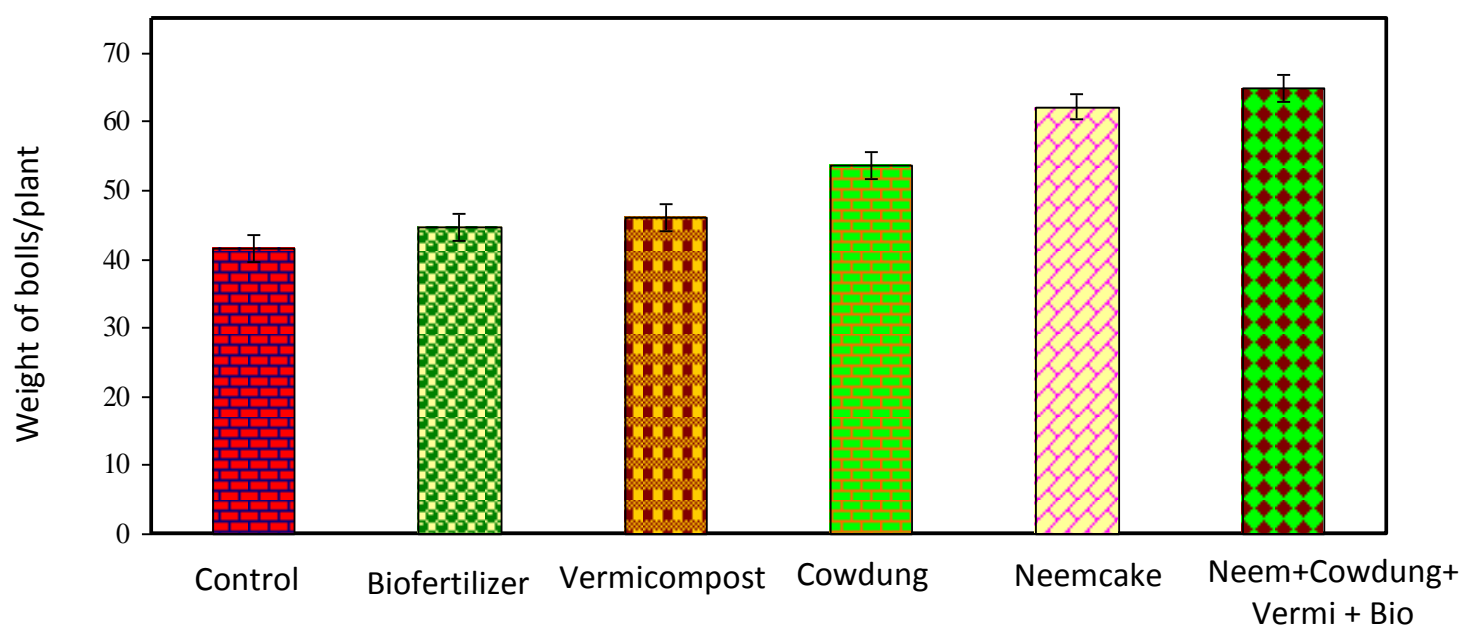

Fig. 10: Effect of different soil amendments on weight of bolls/plant of cotton (Gossypium hirsutum L.). DAS - days after sowing. Error bars indicate \pm SD.

\section{Conclusion}

The application of biofertilizer, vermicompost, cow dung, neem cake and combined application significantly increased the plant growth, biochemical properties, number of bolls and weight of bolls per plant. The results obtained revealed that cotton plant, Gossypium hirsutum L. responded well to the application of neem cake and combined application soil amendments compared to other organic manures and control treatment. Based on the findings of this study, it may be recommended that combined application soil amendments is adequate for maximum growth and yield cotton (Gossypium hirsutum L.).

\section{Conflict of interest statement}

Authors declare that they have no conflict of interest.

\section{References}

Bachmann, F., 2012. Potential and limitations of organic and fair trade cotton for improving livelihoods of smallholders: evidence from Central Asia. Renew. Agric. Food Syst. 27(02), 138-147.

Dubois, M., Cilles, K.A., Hamilton, J.K., Rebers, P.A., Smith, F., 1956. Colorimetric method for determination of sugars and related substances. Anal. Chem. 28, 350-356. 
Dumka, D., Bednarz, C.W., Maw, B.W., 2004. Delayed initiation of fruiting as a mechanism of improved drought avoidance in cotton. Crop Sci. 44, 528-534.

Falaki, A. M., Mike, S., Abubakar, I. U., 1992. Fertilizer use, practice under irrigation. A paper presented at the 3 rd National fertilizer workshop, Ibadan, Nigeria. 12p.

FAO, 2009. FAO Statistical Database. Food and Agriculture Organization of the United Nations. www.http://faostat.fao.org.

Karmegam, N., Daniel, T., 2008. Effect of vermicompost and chemical fertilizer on growth and yield of hyacinth bean (Lablab purpureus). Dyn. Soil Dyn. Plant. 2(2), 77-81.

Kimenju, J.W., Muiru, D.M., Karanja, N.K., Nyongesa, M.W., Miano, D.W., 2004. Assessing the role of organic amendments in management of root-knot nematodes on common bean, Phaseolus vulgaris L. Trop. Microbiol. Biotechnol. 3, 14-23.

Kumar, V., Singh, K. P., 2001. Enriching vermicompost by nitrogen fixing and phosphate solubilizing bacteria. Bioresour. Technol. 76,
173-175.

Lowry, O.H., Rosenbrough, N.J., Farr, A.L., Randall, R.J., 1951. Protein measurement with Folinphenol reagent. J. Biol. Chem. 193, 265-275.

Moore, S., Stein, W. H., 1948. Photometric method for use in the chromatography of amino acids. J. Biol. Chem., 176-388.

Nelson, N., 1944. A photometric adaptation of the sromogysis method for the determination of reducing sugar. Anal. Chem. 3, 426-428.

Oliveira, N. L. C., Puiatti, M., Santos, R. H. S, Cecon, P. R., Rodrigues, P. H. R., 2009. Soil and leaf fertilization of lettuce crop with cow urine. Horticul. Brasil. 27(4), 431-437.

Sankaranarayanan, K., Nalayini, P., Sabesh, M., Usha Rani, S., Nachane, R.P., Gopalakrishnan, N., 2011. Low Cost Drip-Cost Effective and Precision Irrigation Tool in Bt Cotton. Technical Bulletin No.1/2011, Published by Central Institute for Cotton Research, Regional Station, Coimbatore 641003.

Shivagaje, A., Kasture, M., Yadav, D., Pandharikar, N., Mathankar, M., 2004. Cotton scenario in India. Curr. Sci. 87, 15-26.

\section{How to cite this article:}

Annadurai, R., Nelson, R., 2018. Effect of application of vermicompost, cowdung, neem cake and biofertilizer on growth and yield responses of cotton (Gossypium hirsutum L.). Int. J. Curr. Res. Biosci. Plant Biol. 5(7), 70-76. doi: https://doi.org/10.20546/ijcrbp.2018.507.009 